\title{
Trace Element Concentrations in Bearded Seals (Erignathus barbatus) Near Red Dog Mine Compared to Other Locations in Alaska
}

\author{
Lori Quakenbush and John J. Citta \\ Alaska Department of Fish and Game, 1300 College Road, Fairbanks, AK 99701, USA \\ Correspondence should be addressed to Lori Quakenbush, lori.quakenbush@alaska.gov \\ Received 17 August 2008; Revised 12 November 2008; Accepted 3 January 2009 \\ Recommended by Tracy K. Collier
}

To determine if bearded seals (Erignathus barbatus) harvested near a zinc and lead mine (Red Dog, Alaska, USA) by subsistence hunters from Kivalina, Alaska, were as safe to eat as bearded seals from other locations in Alaska, we compared 19 trace element concentrations in liver tissue. Liver concentrations from nine bearded seals harvested near the Red Dog Mine (RDM) port site were compared with 15 bearded seals from two reference sites (Hooper Bay and Little Diomede, Alaska, USA). Concentrations did not differ by gender, but we found statistically significant trends in concentrations of cadmium, mercury, manganese, selenium, and vanadium with age. Arsenic and copper were the only elements found to be more concentrated in the liver of bearded seals harvested near RDM than in the other locations. The predominant form of arsenic in marine mammals is known to be a nontoxic organic form, not the toxic inorganic form, and copper is an essential element. Although elevated near RDM, neither element was found at concentrations that presented health risks. We found no evidence that bearded seals harvested near RDM were less safe to eat or that trace element concentrations were greater than those found in bearded seals harvested elsewhere in Alaska or Canada.

Copyright (C) 2009 L. Quakenbush and J. J. Citta. This is an open access article distributed under the Creative Commons Attribution License, which permits unrestricted use, distribution, and reproduction in any medium, provided the original work is properly cited.

\section{Introduction}

Kivalina, Alaska, USA is a village of approximately 375 people located $129 \mathrm{~km}$ from the city of Kotzebue in northwestern Alaska on the coast of the Chukchi Sea (Figure 1). The population is $97 \%$ Inupiat Eskimo who obtain much of their food from local marine and terrestrial resources. Concerns regarding food safety have arisen due to studies that have shown contaminants are found in the Arctic, great distances from where they are produced and used (see review in Bard [1]) and there has been an increase in local industrial activity related to mineral and petroleum extraction. One potential source of local contamination is the Red Dog Mine, an open-pit zinc and lead mine located approximately $80 \mathrm{~km}$ northeast of Kivalina. The mine is operated by Teck Cominco and has been in operation since 1989. Ore is transferred from the mine to a nearby processing facility, where it is crushed and concentrated. The ore is then trucked to the port site, approximately $29 \mathrm{~km}$ southeast of Kivalina, where it is stored until it can be loaded on barges and transferred to cargo ships. Dust from ore removal and transportation has been identified as a source of heavy metal contamination $[2,3]$. Based upon these findings, numerous assessments have quantified the risks of contamination for people using local resources for food (e.g., [4-8]). Although studies of marine sediments identified elevated concentrations of barium, cadmium, chromium, copper, silver, strontium, and zinc near Red Dog Mine port site, no contaminants exceeded the screening standards used to assess human health (see description of screening standards [7]). For this reason, contaminant concentrations in marine mammals near the Red Dog Mine port site have not been assessed.

However, marine mammals, especially bearded seals (Erignathus barbatus), are an important local subsistence resource (Alaska Department of Fish and Game (ADF\&G), Alaska, USA unpublished data, available at www.subsistence.adfg. state.ak.us/CSIS/, [9]). During public meetings with Teck Cominco, area residents expressed 


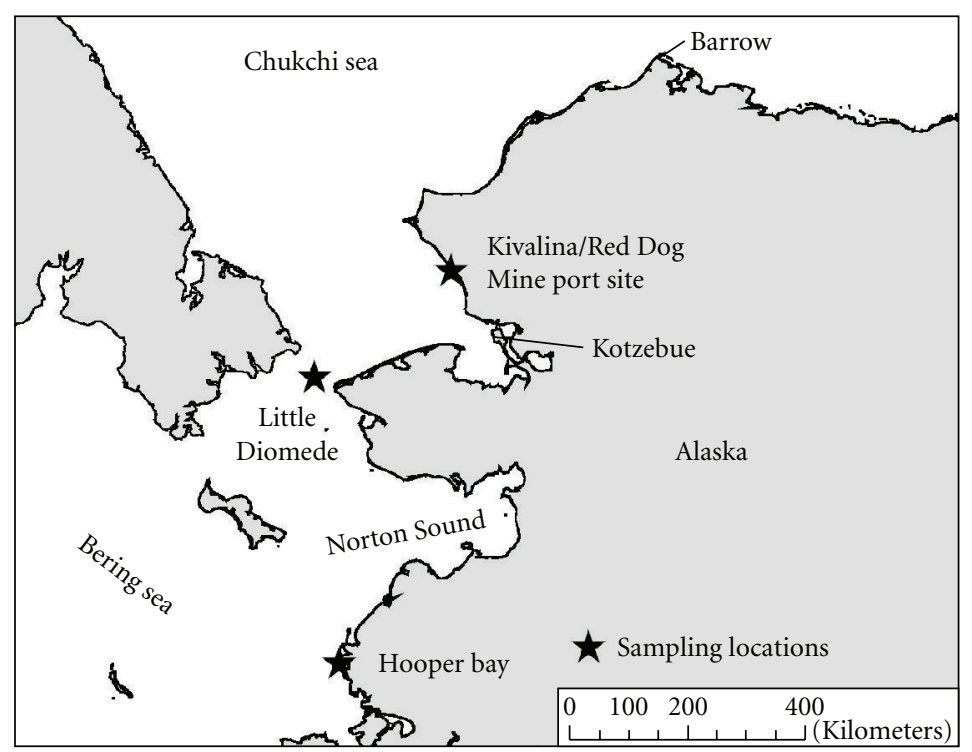

FIGURE 1: Harvest locations for bearded seals sampled for trace element concentrations.

concern that mine-related contaminants may make bearded seals unsafe to eat $[10,11]$. Bearded seals near Kivalina are known to eat invertebrates (crabs, shrimp, and clams) and fish (cod and sculpins) [12] that feed on or near the bottom and therefore may ingest contaminants from their food sources and directly from marine sediments while foraging. In response to this concern, $\mathrm{ADF} \& \mathrm{G}$ agreed to work with local subsistence hunters and Teck Cominco to determine trace element (including heavy metal) concentrations in tissues from bearded seals.

The purpose of this study was to determine if bearded seals harvested in the vicinity of the mine were as safe to eat as bearded seals from other locations in Alaska. We compared trace element concentrations in bearded seals harvested by Kivalina hunters near the Red Dog Mine (RDM) port site with bearded seals harvested where no mining was occurring. We did not attempt to determine if mine-related activities were contaminating seals. Because there was no systematic monitoring program in place for contaminants in this area, we used a retrospective approach and compared the bearded seals harvested by Kivalina hunters near the RDM in 2005 with bearded seals harvested near Little Diomede and Hooper Bay, Alaska, in 2003-2005, where no mining was occurring.

\section{Methods}

Bearded seal teeth and liver tissue were contributed by hunters from Kivalina, Alaska (see Figure 1) in June 2005 and from Little Diomede and Hooper Bay in 2003, 2004, and 2005. Liver was chosen for sampling because many elements bioaccumulate in liver tissue and data from liver tissue is available from other studies for comparison. Although muscle and blubber are the tissues most consumed by people, neither are good tissues for evaluating and comparing trace elements. Although sampling other tissues or substances, such as stomach contents or blood, may be better for determining levels of contaminants directly available in the local environment, our focus was whether bearded seals harvested near RDM were less safe to consume than bearded seals harvested from other areas.

2.1. Trace Element Analyses. Liver tissues were frozen in Ziploc bags and transported to ADF\&G in Fairbanks. Tissues were then subsampled under clean conditions using titanium knives on a Teflon covered surface [13]. Clean samples were placed in I-Chem glass jars and stored at $-55^{\circ} \mathrm{C}$. Samples were analyzed by LET Laboratories in Columbia, Missouri, USA. The laboratory quantified the concentration $(\mu \mathrm{g} / \mathrm{g}$ or ppm dry weight) of aluminum (Al), arsenic (As), boron (B), barium $(\mathrm{Ba})$, beryllium $(\mathrm{Be})$, cadmium $(\mathrm{Cd})$, chromium $(\mathrm{Cr})$, copper $(\mathrm{Cu})$, iron $(\mathrm{Fe})$, mercury $(\mathrm{Hg})$, magnesium $(\mathrm{Mg})$, manganese $(\mathrm{Mn})$, molybdenum (Mo), nickel (Ni), lead $(\mathrm{Pb})$, selenium $(\mathrm{Se})$, strontium $(\mathrm{Sr})$, vanadium $(\mathrm{V})$, and zinc $(\mathrm{Zn})$. Silver $(\mathrm{Ag})$ was not included because it would have required contracting another laboratory at additional cost and although $\mathrm{Ag}$ has been found at relatively high concentrations in beluga whales in Alaska [14], there are no studies regarding its toxicity. With no way to evaluate the results, we did not feel the additional cost was warranted.

Liver samples were first homogenized with a meat grinder. An aliquot of approximately $100 \mathrm{~g}$ was weighed and freeze-dried and then further homogenized using a blender prior to extraction. Percent moisture was calculated by comparing the weight of the wet sample with the weight of the dry samples before a $0.5 \mathrm{~g}$ sample was extracted and digested in a microwave wet ash procedure using $\mathrm{H}_{2} \mathrm{O}_{2}$ and $\mathrm{HCl}$. Percent moisture was used to convert dry weight to wet weight and all results are presented in $\mu \mathrm{g} / \mathrm{g}$ wet weight. Microwave digestion was used for all elements except As and Se. 
Samples analyzed for As and Se were digested using magnesium dry ash digestion methods. This method uses methanol, $\mathrm{HNO}_{3}, \mathrm{HCl}$, and heat for digestion. After digestion, As and Se were analyzed using hydride generation $\mathrm{AA} . \mathrm{Pb}$ was analyzed using graphite furnace AA. For total mercury, a $10 \mathrm{~mL}$ aliquot was removed immediately after dilution, $\mathrm{HCl}$ was added, and concentrations were determined using cold vapor AA. All other elements were analyzed using ICP on a Perkin Elmer 4300 DV.

Quality assurance included the analysis of procedural blanks, duplicate samples, and spiked samples run with each group of 10 samples. Instruments were also calibrated after every 10 samples. If quality standards were not met samples were rerun. Standard reference materials (SRM) provided by the National Institute of Standards and Technology (NIST 1566b, oyster tissue) and the National Research Council, Canada (NRCC DOLT-3, dogfish liver) were used. The data were accepted if the SRM reported value was within 2 standard deviations of the certified mean of the SRM. LET Laboratories participates in annual interlaboratory trials to maintain quality assurance and comparability with other participating laboratories.

2.2. Aging. Lower jaws were submerged in hot water for 30 minutes and a canine tooth was extracted and placed in a paper envelope. Teeth were sent to Matson's Laboratory in Milltown, MT, USA for slide preparation. Teeth were sectioned $(14 \mu \mathrm{m})$, placed on glass slides, and stained with Giemsa histological stain. Age was determined by counting growth layer groups that are generally accepted to represent one per year [15], although validation studies are lacking. Bearded seal teeth show excessive wear at early ages and lower canines have been reported to be missing frequently [16], which can make accurate aging problematic [17]. Lower canines were present in our specimens and Matson's Laboratory provided ages accompanied by a certainty code that described the potential error associated with the ages. The error associated with aging ranged from 0 to 4 years, with a mean of 2 years.

2.3. Statistical Analyses. To compare RDM to sites without possible mine contamination, we pooled samples from Little Diomede and Hooper Bay and treated them as a reference group. For concentrations below the detection limit, we followed the standard practice of assigning one half the detection limit for calculating statistics such as means (e.g., [6]); however, no statistical analyses were conducted when $>50 \%$ of samples had concentrations below the detection limit.

Our data presented two obstacles for analysis. First, our sample sizes were small, making the assumptions required by parametric tests difficult to assess. Second, because concentrations of some elements are known to covary with age [1719] and/or gender [19], we were concerned that sites may have sample compositions with different age or sex ratios, thereby confounding differences in element concentrations. For example, if the RDM sample was composed of older seals, we may incorrectly conclude that there was greater contamination there for a contaminant that bioaccumulates with age. To assess if element concentrations differed by gender or location, we used nonparametric Mann-Whitney $U$ statistics (see [20], page 146). Exact $P$-values were calculated using PROC NPAR1WAY in SAS 9.1 [21]. To assess gender effects, we used 2-sided tests. Because we wanted to know if seals harvested near RDM had higher element concentrations, we used 1-sided tests when comparing locations. To control for age effects, we used parametric tests using age as a covariate. Because tests of normality are known to have low power [20], we primarily relied on nonparametric procedures and only applied the parametric test to control for age when the element was identified as covarying with age. For parametric comparisons, we first $\log$ transformed element concentrations and then fit a linear model with age treated as a continuous covariate. The model was specified as $\ln \left(y_{i}\right)=\beta_{0}+\beta_{1} x_{i 1}+\beta_{2} x_{i 2}+\varepsilon_{1}$, where $y$ is concentration $(\mu \mathrm{g} / \mathrm{g})$ for seal $i, x_{1}$ is a dummy variable $(0,1)$ that adjusts the mean for site (RDM or reference), $x_{2}$ is seal age (years), and $\varepsilon$ is residual error. This is analogous to an ANCOVA model, where site is a categorical variable and age is a continuous covariate. We fit age effects with a simple linear model, as we did not have enough samples to reliably estimate separate slope parameters for RDM and reference sites or to identify nonlinear relationships between element concentrations and age. Although we know that the bioaccumulation of contaminants is likely nonlinear and probably differs by sampling locations, modeling age as a linear covariate still eliminated much of the variance among seals of different ages. We investigated fitting curvilinear models to the data and found that such models sometimes identified patterns that were clearly spurious. Choosing to model age effects as linear is a major improvement over assuming the same age distributions exist between the RDM sample and the control sample and therefore provides the best balance between over and under parameterizing the models we used. For elements without a significant age effect (i.e., if the slope was not significantly different from 0 at $P \leq .05$ ), we relied upon Mann-Whitney $\mathrm{U}$ statistics.

\section{Results}

We obtained liver samples from 24 bearded seals, nine from $\mathrm{RDM}$, and 15 from reference sites (nine from Little Diomede and six from Hooper Bay). Five seals from RDM and 12 from reference sites were aged. Seals ranged from $<1$ to 23 years old; seals sampled near RDM averaged 11.2 years of age and seals sampled at reference sites averaged 7.1 years of age. Of 19 elements analyzed, eight (Al, B, Ba, Be, Cr, $\mathrm{Mo}, \mathrm{Ni}, \mathrm{Pb}$ ) were detected in fewer than $50 \%$ of samples, from both RDM and reference sites and eight others $(\mathrm{Cu}$, $\mathrm{Fe}, \mathrm{Hg}, \mathrm{Mg}, \mathrm{Mn}, \mathrm{Se}, \mathrm{Sr}, \mathrm{Zn}$ ) were detected in all samples from all sites (Tables 1 and 2). Of the elements detected, nonparametric Mann-Whitney tests identified no differences in element concentrations by gender at the $P=.05$ level. $\mathrm{As}, \mathrm{Cu}, \mathrm{Hg}$, and Se were identified as having significantly higher concentrations near RDM (Table 2). Both Hg and Se varied significantly with age; however, once age effects were controlled for, concentrations were not significantly different 
between locations. $\mathrm{Cu}$ and As did not vary significantly with age; therefore, it appears that higher concentrations of $\mathrm{Cu}$ and $\mathrm{As}$ occurred in liver tissues collected near RDM.

\section{Discussion}

Mining-related contamination has been found in marine mammal tissues. Lead and zinc mines in Arctic regions have contaminated local marine environments in both West Greenland [22, 23] and Baffin Island, Canada [24]. In both cases, elevated levels of elements were found in marine sediments and invertebrates near port sites or near tailings dumps, relative to pre-mining conditions and/or reference sites. On Baffin Island, Wagemann [18] followed up the work of Fallis [24] and found elevated levels of lead in liver and muscle tissue and elevated selenium in muscle tissue in ringed seals (Phoca hispida) collected near the Nanisivik Mine port site compared with a reference site. Prior to Wagemann's [18] study, Fallis [24] reported that the mine concentrates were likely entering the marine environment via runoff, wind, and spills when loading the concentrate onto ships at the port site. These pathways are similar to that described for the entry of mine concentrate into the marine environment near RDM [7]. Lead and zinc concentrates from $\mathrm{RDM}$ are known to have concentrations of $\mathrm{Al}, \mathrm{Ba}$, $\mathrm{Cd}, \mathrm{Cu}, \mathrm{Pb}$, and $\mathrm{Zn}$ in excess of $1000 \mathrm{ppm}$ [7, Table 2-1]. Although mines occur in areas that have naturally high concentrations of elements, studies have concluded that excavating and transporting the ore have elevated element concentrations near RDM facilities relative to local reference samples (e.g., $[2,3])$. Hence, local concerns regarding food safety are justified.

Although such concerns are justified, it is unclear whether high contaminant concentrations would be transferred to bearded seals even if they were present because they may not spend much time feeding there. For example, ringed seals that were believed to feed near the Nanisivik Mine on Baffin Island, Canada were found to have elevated levels of $\mathrm{Mg}, \mathrm{Pb}$, and $\mathrm{Cd}$ [18]. On the contrary, short-finned pilot whales (Globicephala macrohynchus) and pygmy sperm whales (Kogia breviceps) that stranded on the coast of New Caledonia, where local sediments and food webs were known to be contaminated with high levels of $\mathrm{Co}, \mathrm{Cr}, \mathrm{Fe}$, and $\mathrm{Ni}$, did not show elevated concentrations of mine-related elements, probably because the whales were not regularly feeding in inshore waters [25].

We do not know how much time bearded seals spend feeding near RDM, but available information indicates that bearded seals may be highly mobile. During the fall seasons of 2004-2006, 26 bearded seal pups were captured and fitted with satellite transmitters near Kotzebue [26]. After tagging, the pups left Kotzebue Sound by the end of October or early November, with several moving $300-400 \mathrm{~km}$ in the first few weeks. None lingered near Kivalina or RDM, although several transited through this area. Extrapolations and assumptions based on Kotzebue tag data, however, should be made with caution because it is unknown how pup movement patterns compare to adult movement patterns.
Also, these pups were tagged at the end of the open-water season as they were beginning to leave the area and we do not know how movement patterns may change by season. Regardless, a better understanding of the movement patterns of seals near RDM would help us understand the potential for exposure to mine-related elements and would also help us interpret observed element concentrations.

We found little evidence that the concentrations of trace elements were elevated in the liver tissue of bearded seals sampled near RDM compared to our reference sites. Concentrations of $\mathrm{Cd}, \mathrm{Pb}$, and $\mathrm{Zn}$ in liver tissue from $\mathrm{RDM}$ were not statistically greater than what was observed at reference sites (Table 2). In fact, $\mathrm{Pb}$ was below detection limits in all of the RDM samples. After accounting for how elements accumulate with age, only $\mathrm{As}$ and $\mathrm{Cu}$ were more concentrated in seal liver near RDM than in the other locations we sampled (Tables 1 and 2).

Arsenic is found widely in marine and freshwater environments and has both natural (volcanic) and anthropogenic (industrial and agricultural) sources [27]. Higher concentrations of As near RDM are probably not related to mining activities. Although studies have found high levels of As in stream sediments [28] and caribou tissues $[8,29]$, the concentration of As in ore from RDM has been shown to be no higher than that observed within local soil samples [7]. Hence, higher concentrations of As may occur naturally within the RDM region.

Concentration of As does not increase with trophic level and lower level consumers have the highest concentrations, suggesting that As does not biomagnify [30]. In general, species feeding on cephalopods and crustaceans tend to have higher concentrations [30]. As such, we might expect bearded seals to have higher concentrations. In agreement with Kubota et al. [30], we found that As concentrations were not influenced by age or gender. Although many forms of As occur, including the highly toxic inorganic form, the predominant form found in marine mammals is the relatively nontoxic organic form called arsenobetaine [3133]. Kunito et al. [33] found that arsenobetaine composed between 68 and $98 \%$ of extractable arsenic in four species of marine mammals, including bearded seals (68\%). As such, the health risks of As may be low even with high concentrations of total As in tissue [33]. Little is known about concentrations that are problematic for seals or their predators; however, a review of contaminants in marine mammals that included the levels reported here did not recognize any studies that reported toxic levels of As [34]. Domestic livestock show toxicity at levels of $14-15 \mu \mathrm{g} / \mathrm{g}$ wet weight [35]. Levels of As below $0.8 \mu \mathrm{g} / \mathrm{g}$ wet weight are considered to be very low by Alaska Department of Health and Social Services, Alaska, USA [36].

Most trace elements are found in the highest concentrations in organ tissues; however, organic As has been found at higher levels in seal blubber [32]. Mean blubber concentrations (range $0.60-1.76 \mu \mathrm{g} / \mathrm{g}$ wet weight) were 2.4 times higher than liver concentrations (range $0.19-0.74 \mu \mathrm{g} / \mathrm{g}$ wet weight) in 18-ringed seals from Canada [32]. Hence, levels of As in bearded seal blubber might be much higher than what we observed in liver tissue. There are no comparable studies for 
TABLE 1: Trace element concentrations ( $\mu \mathrm{g} / \mathrm{g}$ wet weight) in bearded seal liver samples from nine seals harvested near the Red Dog Mine port site (RDM) and 15 seals harvested near reference sites. Concentrations are summarized as arithmetic and geometric means, arithmetic standard deviations, and ranges. Detection limits are presented in Table 2. Elements in which concentrations were found to be significantly different between sites are in bold.

\begin{tabular}{|c|c|c|c|c|c|}
\hline Element & Site & $\begin{array}{l}\text { Arithmetic mean } \\
\text { ( } \mu \mathrm{g} / \mathrm{g} \text { wet weight) }\end{array}$ & $\begin{array}{l}\text { Geometric mean } \\
\text { ( } \mu \mathrm{g} / \mathrm{g} \text { wet weight) }\end{array}$ & Arithmetic SD & Range \\
\hline \multirow[t]{2}{*}{$\mathrm{Al}$} & $\mathrm{RDM}$ & 1.10 & 1.03 & 0.46 & $0.84-1.91$ \\
\hline & reference & 0.61 & 0.50 & 0.45 & $0.29-1.72$ \\
\hline \multirow[t]{2}{*}{ As } & $\mathrm{RDM}$ & 0.58 & 0.52 & 0.28 & $0.22-1.15$ \\
\hline & reference & 0.41 & 0.31 & 0.32 & $0.04-1.13$ \\
\hline \multirow[t]{2}{*}{ B } & $\mathrm{RDM}$ & 0.28 & 0.28 & 0.01 & $0.27-0.3$ \\
\hline & reference & 0.36 & 0.34 & 0.17 & $0.28-0.89$ \\
\hline \multirow[t]{2}{*}{$\mathrm{Ba}$} & RDM & 0.09 & 0.08 & 0.07 & $0.07-0.29$ \\
\hline & reference & 0.03 & 0.03 & 0.00 & $0.03-0.03$ \\
\hline \multirow[t]{2}{*}{$\mathrm{Be}$} & RDM & 0.01 & 0.01 & 0.00 & $0.01-0.01$ \\
\hline & reference & 0.01 & 0.01 & 0.00 & $0.01-0.02$ \\
\hline \multirow[t]{2}{*}{$\mathrm{Cd}$} & RDM & 5.24 & 4.25 & 2.99 & $0.97-10.59$ \\
\hline & reference & 7.12 & 0.94 & 11.16 & $0.01-39.93$ \\
\hline \multirow[t]{2}{*}{$\mathrm{Cr}$} & $\mathrm{RDM}$ & 0.07 & 0.07 & 0.00 & $0.07-0.07$ \\
\hline & reference & 0.13 & 0.07 & 0.19 & $0.01-0.77$ \\
\hline \multirow[t]{2}{*}{$\mathrm{Cu}$} & RDM & 40.71 & 38.72 & 13.80 & $19.84-70.74$ \\
\hline & reference & 24.65 & 21.82 & 12.12 & $7.8-42.78$ \\
\hline \multirow[t]{2}{*}{$\mathrm{Fe}$} & $\mathrm{RDM}$ & 598.40 & 589.44 & 108.23 & $421.5-781.44$ \\
\hline & reference & 620.09 & 575.16 & 238.49 & $272.91-1078.68$ \\
\hline \multirow[t]{2}{*}{$\mathrm{Hg}$} & $\mathrm{RDM}$ & 3.23 & 3.08 & 1.05 & $1.92-5.22$ \\
\hline & reference & 3.93 & 1.25 & 7.28 & $0.13-28.31$ \\
\hline \multirow[t]{2}{*}{$\mathrm{Mg}$} & RDM & 185.36 & 184.80 & 15.58 & $168.02-216.75$ \\
\hline & reference & 183.76 & 182.62 & 20.09 & $127.88-218.73$ \\
\hline \multirow[t]{2}{*}{$\mathrm{Mn}$} & RDM & 5.09 & 5.02 & 0.84 & $3.52-6.29$ \\
\hline & reference & 4.51 & 4.36 & 1.25 & $2.67-6.78$ \\
\hline \multirow[t]{2}{*}{ Mo } & $\mathrm{RDM}$ & 0.35 & 0.33 & 0.13 & $0.27-0.58$ \\
\hline & reference & 0.34 & 0.33 & 0.10 & $0.28-0.61$ \\
\hline \multirow[t]{2}{*}{$\mathrm{Ni}$} & $\mathrm{RDM}$ & 0.08 & 0.08 & 0.02 & $0.07-0.14$ \\
\hline & reference & 0.07 & 0.06 & 0.02 & $0.03-0.08$ \\
\hline \multirow[t]{2}{*}{$\mathrm{Pb}$} & RDM & 0.03 & 0.03 & 0.00 & $0.03-0.03$ \\
\hline & reference & 0.04 & 0.04 & 0.02 & $0.03-0.09$ \\
\hline \multirow[t]{2}{*}{$\mathrm{Se}$} & $\mathrm{RDM}$ & 4.79 & 4.68 & 1.10 & $3.4-6.5$ \\
\hline & reference & 4.35 & 3.19 & 4.58 & $1.29-18.48$ \\
\hline \multirow[t]{2}{*}{$\mathrm{Sr}$} & RDM & 0.21 & 0.18 & 0.14 & $0.12-0.57$ \\
\hline & reference & 0.28 & 0.21 & 0.34 & $0.09-1.47$ \\
\hline \multirow[t]{2}{*}{$\mathrm{V}$} & $\mathrm{RDM}$ & 0.70 & 0.41 & 0.88 & $0.07-2.9$ \\
\hline & reference & 0.29 & 0.18 & 0.30 & $0.07-1.01$ \\
\hline \multirow[t]{2}{*}{$\mathrm{Zn}$} & RDM & 62.45 & 62.26 & 5.09 & $54.91-68.85$ \\
\hline & reference & 62.85 & 59.19 & 23.07 & $30.83-115.19$ \\
\hline
\end{tabular}


TABLE 2: Statistical comparisons of trace element concentrations in bearded seal liver tissue between Red Dog Mine port site (RDM) and reference sites. No statistical tests were conducted when trace elements were detected in less than 50\% of samples. ANCOVA was used to control for possible age effects when the nonparametric Mann-Whitney test identified differences in trace metals concentrations between RDM and reference samples. Trace elements detected in more than $50 \%$ of samples that Mann-Whitney tests identified as statistically different between RDM and reference sites are in bold.

\begin{tabular}{|c|c|c|c|c|c|c|c|}
\hline \multirow[b]{2}{*}{ Element } & \multirow{2}{*}{$\begin{array}{c}\text { Minimum } \\
\text { detection } \\
\text { limit } \\
\text { ( } \mu \mathrm{g} / \mathrm{g} \text { wet } \\
\text { weight })\end{array}$} & \multicolumn{2}{|c|}{ Proportion of samples above detection limit } & \multirow[b]{2}{*}{$\begin{array}{l}\text { Above threshold } \\
\text { for statistical } \\
\text { analyses? }\end{array}$} & \multirow[b]{2}{*}{$\begin{array}{c}\text { Mann-Whitney } \\
P\end{array}$} & \multirow[b]{2}{*}{$\begin{array}{l}\text { Significant } \\
\text { age effect? }\end{array}$} & \multirow[b]{2}{*}{ ANCOVA $P$} \\
\hline & & $\operatorname{RDM}(n=9)$ & $\begin{array}{l}\text { Reference sites } \\
\quad(n=15)\end{array}$ & & & & \\
\hline $\mathrm{Al}$ & 1.78 & 0.22 & 0.33 & No & & & \\
\hline As & 0.19 & 1.00 & 0.96 & Yes & .03 & No & - \\
\hline B & 0.62 & 0.00 & 0.08 & No & & & \\
\hline $\mathrm{Ba}$ & 0.15 & 0.11 & 0.04 & No & & & \\
\hline $\mathrm{Be}$ & 0.03 & 0.00 & 0.00 & No & & & \\
\hline $\mathrm{Cd}$ & 0.03 & 1.00 & 0.88 & Yes & .24 & Yes & .53 \\
\hline $\mathrm{Cr}$ & 0.16 & 0.00 & 0.13 & No & & & \\
\hline $\mathrm{Cu}$ & 0.09 & 1.00 & 1.00 & Yes & $<.01$ & No & - \\
\hline $\mathrm{Fe}$ & 0.89 & 1.00 & 1.00 & Yes & .5 & No & - \\
\hline $\mathrm{Hg}$ & 0.3 & 1.00 & 1.00 & Yes & .04 & Yes & .54 \\
\hline $\mathrm{Mg}$ & 1.39 & 1.00 & 1.00 & Yes & .43 & No & - \\
\hline $\mathrm{Mn}$ & 0.16 & 1.00 & 1.00 & Yes & .1 & Yes & .28 \\
\hline Mo & 0.62 & 0.22 & 0.17 & No & & & \\
\hline $\mathrm{Ni}$ & 0.16 & 0.11 & 0.04 & No & & & \\
\hline $\mathrm{Pb}$ & 0.09 & 0.00 & 0.04 & No & & & \\
\hline $\mathrm{Se}$ & 1.19 & 1.00 & 1.00 & Yes & .01 & Yes & .59 \\
\hline $\mathrm{Sr}$ & 0.06 & 1.00 & 1.00 & Yes & .46 & No & \\
\hline $\mathrm{V}$ & 0.16 & 0.89 & 0.63 & Yes & .06 & Yes & .06 \\
\hline $\mathrm{Zn}$ & 0.16 & 1.00 & 1.00 & Yes & .28 & No & \\
\hline
\end{tabular}

bearded seal blubber; however, Becker et al. [13] examined the concentration of As in liver tissues from bearded seals from Norton Sound. Concentrations of As we observed from RDM (arithmetic mean $=0.58 \mu \mathrm{g} / \mathrm{g}$ ) are similar to what Becker et al. [13] observed (range $=0.161-0.577 ; n=3$ ). The amount of organic versus inorganic As is unknown for both our study and Becker et al. [13].

We also found elevated concentrations of $\mathrm{Cu}$ in seal liver near RDM compared to reference sites (Tables 1 and 2). $\mathrm{Cu}$ is known to be more concentrated in soil and marine sediments near the RDM port site [7] and the concentration of $\mathrm{Cu}$ from RDM (arithmetic mean $=40.71 \mu \mathrm{g} / \mathrm{g}$ wet weight) was higher than that for liver tissue from Barrow (arithmetic mean $=22.69 \mu \mathrm{g} / \mathrm{g}$ wet weight, Table 3 ). We do not think that this is a cause for concern, as $\mathrm{Cu}$ is an essential element required for the formation of red blood cells, cell metabolism, neurological function, and the detoxification of free radicals [37]. Cu poisoning in humans generally occurs at concentrations from $1-40 \mathrm{mg} / \mathrm{g}$, which is approximately 100 times greater than what we observed in this study (see review in [38]).

Of the elements that did not differ in concentration between RDM and reference sites (Cd, Hg, Se, Zn, and V), $\mathrm{Hg}$ and Se concentrations are comparable to concentrations found in similar tissues from other locations in Alaska and are lower than concentrations found in Arctic Canada (Table 3). Concentrations of $\mathrm{Zn}, \mathrm{Cd}$, and $\mathrm{V}$ could not be compared to those in Canada, as no data are available for comparison; however, concentrations at both RDM and reference sites are similar to those observed in other locations in Alaska (Table 3).

The overall variability in concentrations of trace elements was generally higher in the reference sample than the RDM sample. Of the elements suitable for statistical tests (i.e., the element was detected in $>50 \%$ of the samples), the standard deviation of element concentration was higher in the reference sample than the RDM sample in 9 of 10 cases (Table 1). The difference in variability was due to fewer low concentrations in the RDM sample (compare ranges in Table 1). In all cases, the minimum concentration observed within the reference sites was lower than that observed within the RDM sample. The larger range of variability within reference samples might be due to a larger proportion of younger seals compared to the RDM sample; the average age within the reference sample was 7.1 years, compared to 11.1 within the RDM sample. This underscores the need to statistically control for age effects where possible. 
TABLE 3: Comparisons of element concentrations in liver of bearded seals between this and other studies. Concentration units are $\mu \mathrm{g} / \mathrm{g}$ wet weight and are summarized as the arithmetic mean and standard deviation for comparison with other studies. Mackey et al. [14] and Becker et al. [13] used the same samples from the Alaska Marine Mammal Tissue Archival Project. We present the results of Mackey et al. [14] except when Becker et al. [13] provide data on different elements.

\begin{tabular}{|c|c|c|c|c|c|c|}
\hline Element & Location & Year & $\begin{array}{l}\text { Liver mean (SD) } \\
\mu \mathrm{g} / \mathrm{g} \text { wet weight }\end{array}$ & $n$ & Mean age (yrs) & Reference \\
\hline \multirow[t]{3}{*}{ As } & Nome, Alaska & 1989-1993 & $0.161-0.577^{(1)}$ & 3 & - & {$[13]$} \\
\hline & This study: reference sites & 2003-2005 & $0.41(0.32)$ & 15 & 7.1 & \\
\hline & This study: RDM & 2005 & $0.58(0.29)$ & 9 & 11.2 & \\
\hline \multirow[t]{4}{*}{$\mathrm{Cd}$} & Nome, Alaska & 1989-1993 & $0.99-2.00^{(1)}$ & 3 & - & {$[14]$} \\
\hline & Pt. Barrow, Alaska & 1998-2001 & $8.66(7.03)$ & 38 & - & [19] \\
\hline & This study: reference sites & 2003-2005 & $7.12(11.16)$ & 15 & 7.1 & \\
\hline & This study: RDM & 2005 & $5.24(3.00)$ & 9 & 11.2 & \\
\hline \multirow[t]{4}{*}{$\mathrm{Cu}$} & Nome, Alaska & 1989-1993 & $6.82-34.44^{(1)}$ & 3 & - & {$[13]$} \\
\hline & Pt. Barrow, Alaska & 1998-2001 & $22.69(7.99)$ & 38 & - & [19] \\
\hline & This study: reference sites & 2003-2005 & $24.65(12.12)$ & 15 & 7.1 & \\
\hline & This study: RDM & 2005 & $40.71(13.80)$ & 9 & 11.2 & \\
\hline \multirow[t]{7}{*}{$\mathrm{Hg}$} & Holman, western Canada & 1973 & $143.00(170.00)$ & 6 & 8.5 & {$[39,40]$} \\
\hline & Belcher island, eastern Canada & 1974 & $26.18(26.13)$ & 56 & 4.9 & {$[40]$} \\
\hline & Alaska & - & $1.91(1.20)$ & 4 & - & {$[41]$} \\
\hline & Nome, Alaska & $1989-1993$ & $1.4-9.4^{(1)}$ & 3 & - & {$[14]$} \\
\hline & Pt. Barrow, Alaska & $1998-2001$ & $3.84(3.55)$ & 34 & - & {$[19]$} \\
\hline & This study: reference sites & 2003-2005 & $3.93(7.28)$ & 15 & 7.1 & \\
\hline & This study: RDM & 2005 & $3.23(1.05)$ & 9 & 11.2 & \\
\hline \multirow[t]{3}{*}{$\mathrm{Pb}$} & Nome, Alaska & $1989-1993$ & 0.03 & 1 & - & {$[13]$} \\
\hline & This study: reference sites & 2003-2005 & $0.04(0.02)$ & 15 & 7.1 & \\
\hline & This study: RDM & 2005 & $0.03(-)^{(2)}$ & 9 & 11.2 & \\
\hline \multirow[t]{6}{*}{ Se } & Holman, western Canada & 1973 & $34.42(33.23)$ & 6 & 8.5 & {$[39,40]$} \\
\hline & Belcher Island, eastern Canada & 1974 & $20.83(13.47)$ & 10 & 4.9 & [40] \\
\hline & Nome, Alaska & 1989-1993 & $0.43-5.3^{(1)}$ & 3 & - & {$[14]$} \\
\hline & Pt. Barrow, Alaska & 1998-2001 & $5.27(3.51)$ & 38 & - & {$[19]$} \\
\hline & This study: reference sites & 2003-2005 & $4.35(4.58)$ & 15 & 7.1 & \\
\hline & This study: RDM & 2005 & $4.79(1.10)$ & 9 & 11.2 & \\
\hline \multirow[t]{3}{*}{$\mathrm{V}$} & Norton Sound, Alaska & $1989-1993$ & $0.15-1.04^{(1)}$ & 3 & - & {$[14]$} \\
\hline & This study: reference sites & 2003-2005 & $0.29(0.30)$ & 15 & 7.1 & \\
\hline & This study: RDM & 2005 & $0.71(0.88)$ & 9 & 11.2 & \\
\hline \multirow[t]{4}{*}{$\mathrm{Zn}$} & Nome, Alaska & 1989-1993 & $32.60-103.70^{(1)}$ & 3 & - & {$[13]$} \\
\hline & Pt. Barrow, Alaska & $1998-2001$ & $57.48(10.37)$ & 38 & - & [19] \\
\hline & This study: reference sites & 2003-2005 & $62.85(23.07)$ & 15 & 7.1 & \\
\hline & This study: RDM & 2005 & $62.45(5.09)$ & 9 & 11.2 & \\
\hline
\end{tabular}

\footnotetext{
(1) Range provided instead of a mean and standard deviation.
}

${ }^{(2)}$ All samples below the detection limit.

Most studies indicate that the concentration of some elements change with animal age (e.g., see reviews in [18, 42]). However, we found no studies on bearded seals that controlled for age effects when making statistical comparisons between sampling locations. Had we simply interpreted mean concentrations without controlling for unequal age distributions, we would have erroneously concluded that higher concentrations of both $\mathrm{Hg}$ and Se occur in bearded seals near RDM. For many studies, animals must be harvested to sample tissues and harvest-based sampling designs are likely not random. Statistical methods that adjust for differences in age or gender are especially important in such instances.

In conclusion, we examined the concentrations of 19 trace elements in the liver tissues of bearded seals harvested near RDM and reference sites. Only As and $\mathrm{Cu}$ were 
found to be elevated near RDM. However, neither of these elements is known to be toxic in the chemical form or at the concentrations found. In addition, the concentrations of $\mathrm{As}$ and $\mathrm{Cu}$ found near RDM although significantly higher than our reference samples, they were not higher than concentrations found elsewhere in Alaska or Canada. Because we found that concentrations of trace elements in bearded seal liver near RDM were not higher than elsewhere, we conclude that muscle tissue, which is more commonly eaten but has much lower concentrations, would also not be higher. Therefore, we found no evidence that bearded seals harvested by hunters near RDM were less safe to eat or that trace element concentrations were greater than those found in bearded seals harvested elsewhere in Alaska or Canada.

\section{Acknowledgments}

This study would not have been possible without the samples provided by hunters from Kivalina, Diomede, and Hooper Bay. G. Sheffield and A. Simon assisted in the collection and shipping of samples from Diomede and Hooper Bay, respectively. J. Norton and A. Swann were helpful in coordinating sample collection in Kivalina. L. Hughes handled the samples once they reached Fairbanks and assisted in the clean sampling for laboratory analysis. C. Eckert and J. Kulas of Teck Cominco Alaska Inc. assisted with logistics and sampling at Kivalina. G. Pickert provided housing at the school in Kivalina. K. Frost, A. Whiting, and $\mathrm{M}$. Cameron provided information on movements of bearded seal pups. S. Shock and M. Gerry of Exponent Inc. reviewed the manuscript. Three anonymous reviewers provided comments that improved the manuscript. Teck Cominco Inc. operators of the Red Dog Mine provided funding for the Kivalina samples to be collected and analyzed. National Oceanic and Atmospheric Administration (NOAA) Fisheries and the National Science Foundation (OPP Grant no. 9910319) provided funding for sample collections at the reference sites and NOAA Fisheries funded the analysis of tissues from the reference sites. All work was done under Marine Mammal Protection Act permit no. 358-1585 issued to $\mathrm{ADF} \& \mathrm{G}$.

\section{References}

[1] S. M. Bard, "Global transport of anthropogenic contaminants and the consequences for the Arctic marine ecosystem," Marine Pollution Bulletin, vol. 38, no. 5, pp. 356-379, 1999.

[2] J. Ford and L. Hasselbach, "Heavy metals in mosses and soils on six transects along the Red Dog mine haul road Alaska," Tech. Rep. NPS/AR/NRTR-2001/38, National Park Service, Denali Park, Alaska, USA, 2001.

[3] L. Hasselbach, J. Ver Hoef, J. Ford, et al., "Spatial patterns of cadmium and lead deposition on and adjacent to National Park Service lands near Red Dog Mine," Tech. Rep. NPS/AR/NRTR-2004-45, National Park Service, Denali Park, Alaska, USA, 2004.

[4] Department of Environmental Conservation, Teck Cominco, and Exponent, "Draft 2001 Fugitive Dust Report. DeLong Mountain Regional Transportation System, Alaska. Unpublished report. Prepared for Teck Cominco Alaska
Inc. Document No. 8601997.00105010102 SS25," Exponent, 15375 30th Place, Suite 250, Bellevue, Wash 98007, USA, 2002, http://www.dec.state.ak.us/spar/csp/docs/reddog/ bibliography.htm\#2001.

[5] Department of Environmental Conservation, "Comments on the Draft DMTS Fugitive Dust Risk Assessment," Alaska Department of Environmental Conservation, Contaminated Sites Program, September 2005, http://www.dec.state.ak.us/ spar/csp/sites/reddog.htm.

[6] Ecology and Environment, Inc., "Wild foods investigation public review draft report Northwest Alaska," Report prepared for the Alaska Department of Environmental Conservation, Division of Air and Water Quality, 2002, http://www.dec .state.ak.us/spar/csp/docs/reddog/bibliography.htm\#2001.

[7] Exponent, "DMTS Fugitive Dust Risk Assessment Volume IReport," Prepared for Teck Cominco Alaska Inc. Document No. 8601997.001 4400 0205 SS14., Exponent, 15375 30th Place, Suite 250, Bellevue, Wash 98007, USA, 2005, http:// www.dec.state.ak.us/spar/csp/docs/reddog/01dmts_ra_summ4 _05.pdf.

[8] T. M. O'Hara, J. C. George, J. Blake, et al., "Investigation of heavy metals in a large mortality event in caribou of northern Alaska," Arctic, vol. 56, no. 2, pp. 125-135, 2003.

[9] Dames \& Moore, L. A. Peterson, S. R. Braund, T. J. Gallagher, and E. Hall, "Environmental Baseline Studies, Red Dog Project," January 1983, Cominco Alaska Inc., Anchorage, Alaska, USA.

[10] Public Meeting Notes, "Red Dog Mine Draft Risk Assessment Meeting with Subsistence Committee," April 2005, http://www.dec.state.ak.us/spar/csp/sites/reddog.htm.

[11] Public Meeting Notes, "Red Dog Mine Draft Risk Assessment Meeting with Kivalina Residents," April 2005, http://www.dec.state.ak.us/spar/csp/sites/reddog.htm.

[12] M. L. Johnson, C. H. Fiscus, B. T. Ostenson, and M. L. Barbour, "Marine mammals," in Environment of the Cape Thompson Region, N. J. Wilimovsky and J. N. Wolfe, Eds., pp. 897-924, U.S. Atomic Energy Commission, Oak Ridge, Tenn, USA, 1966.

[13] P. R. Becker, E. A. Mackey, M. M. Schantz, et al., "Concentrations of chlorinated hydrocarbons, heavy metals and other elements in tissues banked by the Alaska Marine Mammal Tissue Archival Project," U.S. DOC, National Institute of Standards and Technology NISTIR 5620, 1995.

[14] E. A. Mackey, P. R. Becker, R. Demiralp, R. R. Greenberg, B. J. Koster, and S. A. Wise, "Bioaccumulation of vanadium and other trace metals in livers of Alaskan cetaceans and pinnipeds," Archives of Environmental Contamination and Toxicology, vol. 30, no. 4, pp. 503-512, 1996.

[15] R. E. A. Stewart, B. E. Stewart, I. Stirling, and E. Street, "Counts of growth layer groups in cementum and dentine in ringed seals (Phoca hispida)," Marine Mammal Science, vol. 12, no. 3, pp. 383-401, 1996.

[16] I. A. McLaren, "Some aspects of growth and reproduction of the bearded seal, Erignathus barbatus (Erxleben)," Journal of the Fisheries Research Board of Canada, vol. 15, pp. 219-227, 1958.

[17] T. Benjaminsen, "Age determination and the growth and age distribution from cementum growth layers of bearded seals at Svalbard," Fiskeridirektoratets Skrifter. Serie Havunders, vol. 16, pp. 159-170, 1973.

[18] R. Wagemann, "Comparison of heavy metals in two groups of ringed seals (Phoca hispida) from the Canadian Arctic," Canadian Journal of Fisheries and Aquatic Sciences, vol. 46, no. 9, pp. 1558-1563, 1989. 
[19] L.-A. Dehn, G. G. Sheffield, E. H. Follmann, et al., "Trace elements in tissues of phocid seals harvested in the Alaskan and Canadian Arctic: influence of age and feeding ecology," Canadian Journal of Zoology, vol. 83, no. 5, pp. 726-746, 2005.

[20] J. H. Zar, Biostatistical Analysis, Prentice-Hall, Princeton, NJ, USA, 2nd edition, 1998.

[21] SAS Institute, "SAS/STAT Version 9.1," SAS Institute Inc., Cary, NC, USA, 2004.

[22] P. Johansen, M. M. Hansen, G. Asmund, and P. B. Neilsen, "Marine organisms as indicators of heavy metal pollutionexperience from 16 years of monitoring at a lead zinc mine in Greenland," Chemistry and Ecology, vol. 5, no. 1-2, pp. 35-55, 1991.

[23] T. S. Larsen, J. A. Kristensen, G. Asmund, and P. Bjerregaard, "Lead and zinc in sediments and biota from Maarmorilik, West Greenland: an assessment of the environmental impact of mining wastes on an Arctic fjord system," Environmental Pollution, vol. 114, no. 2, pp. 275-283, 2001.

[24] B. Fallis, "Trace metals in sediments and biota from Strathcons Sound, NWT; Nanisivik marine monitoring program, 19741979," Tech. Rep. 1082, Fisheries and Aquatic Sciences, Winnipeg, Manitoba, Canada, 1982.

[25] P. Bustamante, C. Garrigue, L. Breau, et al., "Trace elements in two odontocete species (Kogia briviceps and Globicephala macrohynchus) stranded in New Caledonia (South Pacific)," Environmental Pollution, vol. 124, no. 2, pp. 263-271, 2003.

[26] M. F. Cameron, K. Frost, M. A. Simpkins, L. L. Lowry, J. A. Schaeffer, and A. Whiting, "Diving behavior, habitat use, and movements of bearded seal (Erignathus barbatus) pups in the Bering and Chukchi Seas," in Proceedings of the Alaska Marine Science Symposium, Anchorage, Alaska, USA, January 2007.

[27] J. M. Azcue and J. O. Nriagu, "Arsenic: historical perspectives," in Arsenic in the Environment, Part 1: Cycling and Characterization, J. O. Jriagu, Ed., pp. 1-15, John Wiley \& Sons, New York, NY, USA, 1994.

[28] T. P. Brabets, "Occurrence and distribution of trace elements in snow, streams, and streambed sediments, Cape Krusenstern National Monuments, Alaska, 2002-2003," Scientific Investigation Report 2004-5229, United States Geological Survey, Reston, Va, USA, 2004.

[29] State of Alaska, "Public health evaluation of exposure of Kivalina and Noatak residents to heavy metals from Red Dog Mine," Environmental Public Health Program, Section of Epidemiology, Alaska Division of Public Health. Anchorage, Alaska. pp 52, 2001.

[30] R. Kubota, T. Kunito, and S. Tanabe, "Arsenic accumulation in the liver tissue of marine mammals," Environmental Pollution, vol. 115, no. 2, pp. 303-312, 2001.

[31] W. Goessler, A. Rudorfer, E. A. Mackey, P. R. Becker, and K. J. Irgolic, "Determination of arsenic compounds in marine mammals with high-performance liquid chromatography and an inductively coupled plasma mass spectrometer as elementspecific detector," Applied Organometallic Chemistry, vol. 12, no. 7, pp. 491-501, 1998.

[32] K.-I. Ebisuda, T. Kunito, R. Kubota, and S. Tanabe, "Arsenic concentrations and speciation in the tissues of ringed seals (Phoca hispida) from Pangnirtung, Canada," Applied Organometallic Chemistry, vol. 16, no. 8, pp. 451-457, 2002.

[33] T. Kunito, R. Kubota, J. Fujihara, T. Agusa, and S. Tanabe, "Arsenic in marine mammals, seabirds, and sea turtles," in Reviews of Environmental Contamination and Toxicology, D. M. Whitacre, Ed., pp. 31-69, Springer, New York, NY, USA, 2008.
[34] T. J. O'Shea, "Environmental contaminants and marine mammals," in Biology of Marine Mammals, J. E. Reynolds III and S. A. Rokmmel, Eds., pp. 485-564, Smithsonian Institution Press, Washington, DC, USA, 1999.

[35] C. D. Thatcher, J. B. Meldrum, S. E. Wikse, and W. D. Whittier, "Arsenic toxicosis and suspected chromium toxicosis in a herd of cattle," Journal of the American Veterinary Medical Association, vol. 187, no. 2, pp. 179-182, 1985.

[36] R. A. Ponce, G. M. Egeland, J. P. Middaugh, and P. D. Becker, "Twenty years of trace metal analyses of marine mammals: evaluation and summation of data from Alaska and other Arctic regions," State of Alaska Epidemiology Bulletin, vol. 1, no. 3, pp. 1-15, 1997.

[37] M. C. Linder, Biochemistry of Copper, Plenum Press, New York, NY, USA, 1991.

[38] World Health Organization, "Background document for development of WHO guidelines for drinking-water quality," WHO/SDE/WSH/03.04.88, 2004.

[39] T. G. Smith and F. A. J. Armstrong, "Mercury in seals, terrestrial carnivores, and principal food items of the Inuit, from Holman, N.W.T, Journal of the Fisheries Research Board of Canada, vol. 32, no. 6, pp. 795-801, 1975.

[40] T. G. Smith and F. A. J. Armstrong, "Mercury and selenium in ringed and bearded seal tissues from Arctic Canada," Arctic, vol. 31, no. 2, pp. 75-84, 1978.

[41] W. R. Galster, "Accumulation of mercury in Alaskan pinnipeds," in Proceedings of the 22nd Alaska Science Conference, p. 76, College, Alaska, USA, August 1971.

[42] Northern Contaminants Program, "Canadian Arctic contaminants assessment report II: contaminant levels, trends, and effects in the biological environment," Minister of Public Works and Government Service Canada, Ottawa, Canada, 2003. 

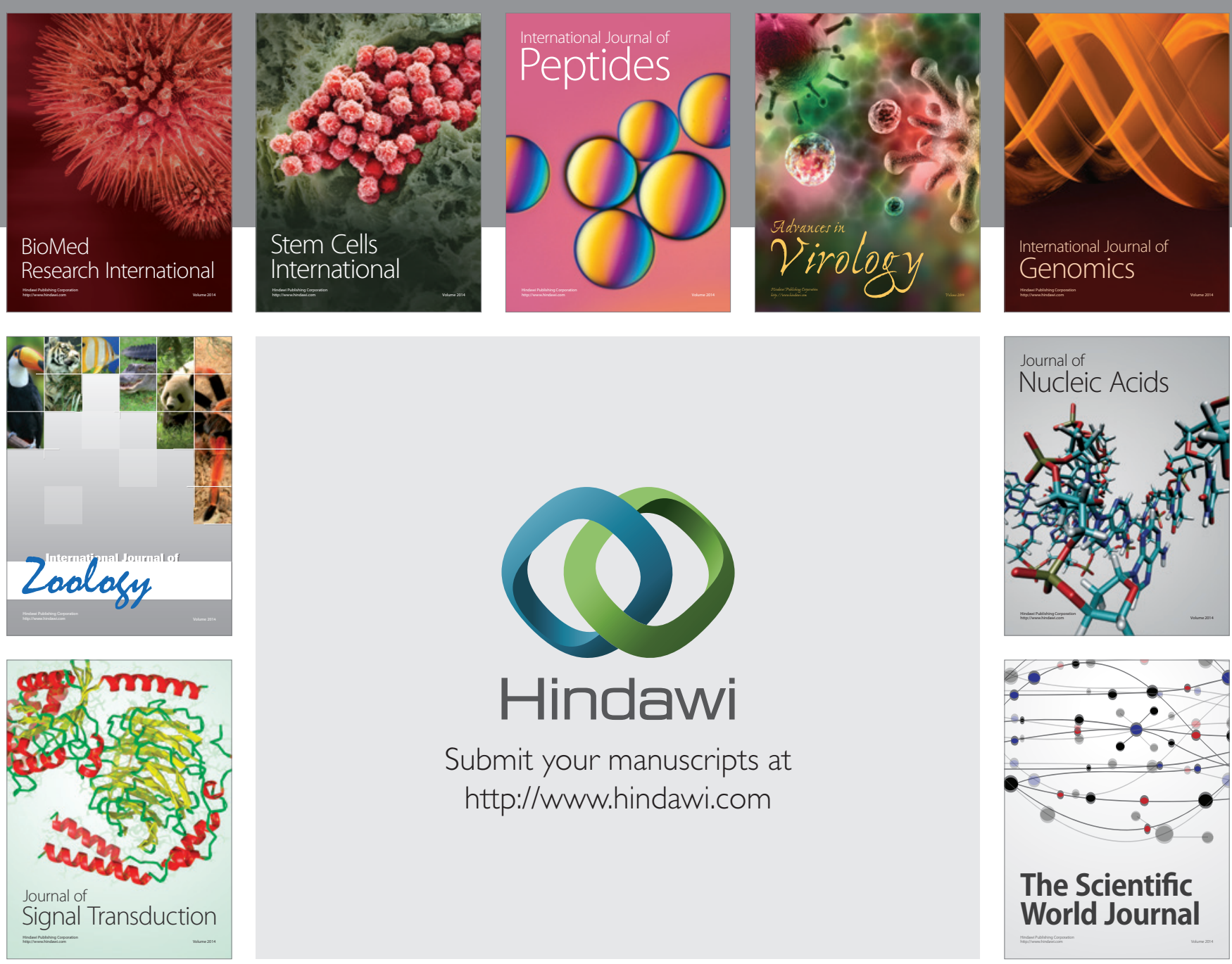

Submit your manuscripts at

http://www.hindawi.com
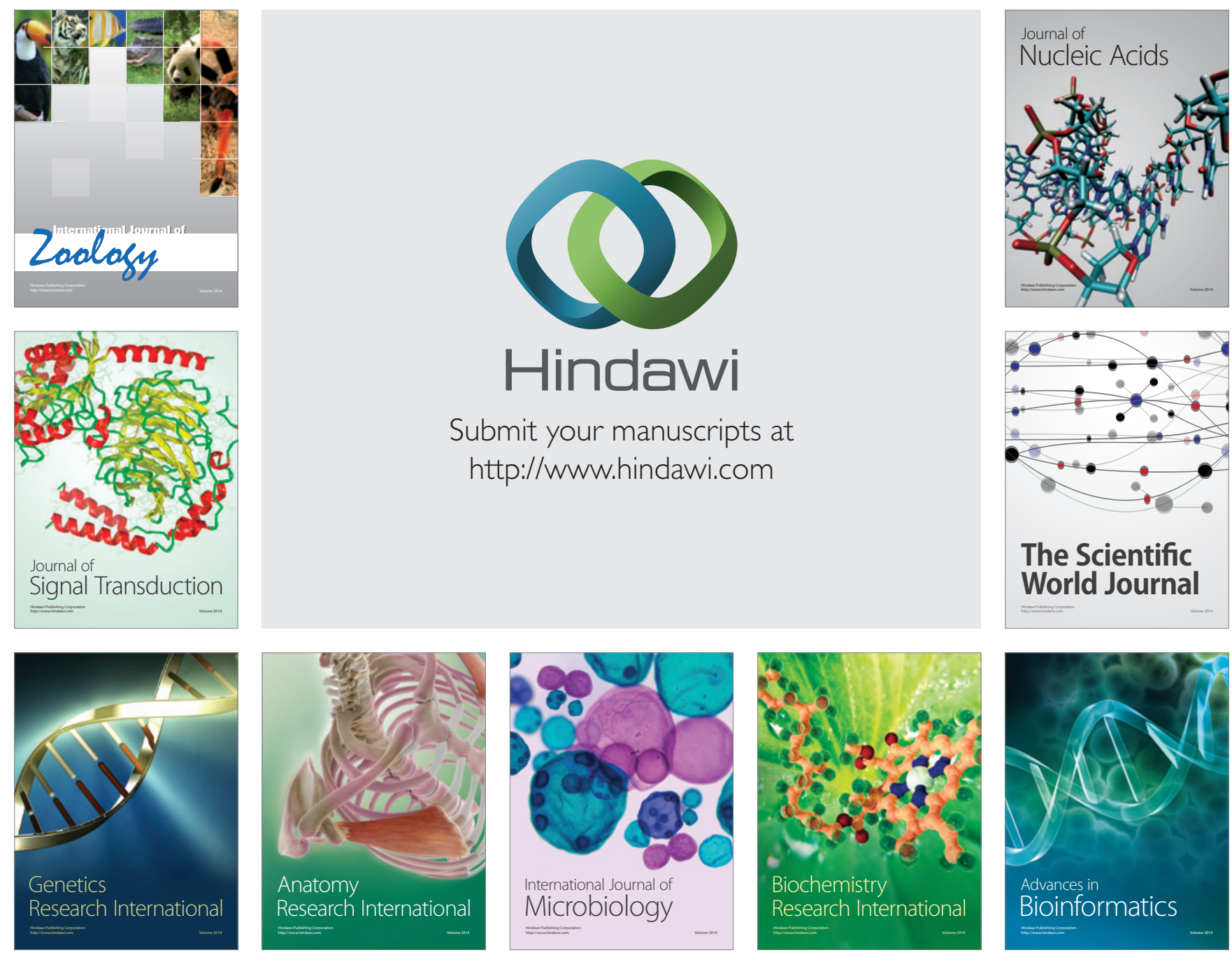

The Scientific World Journal
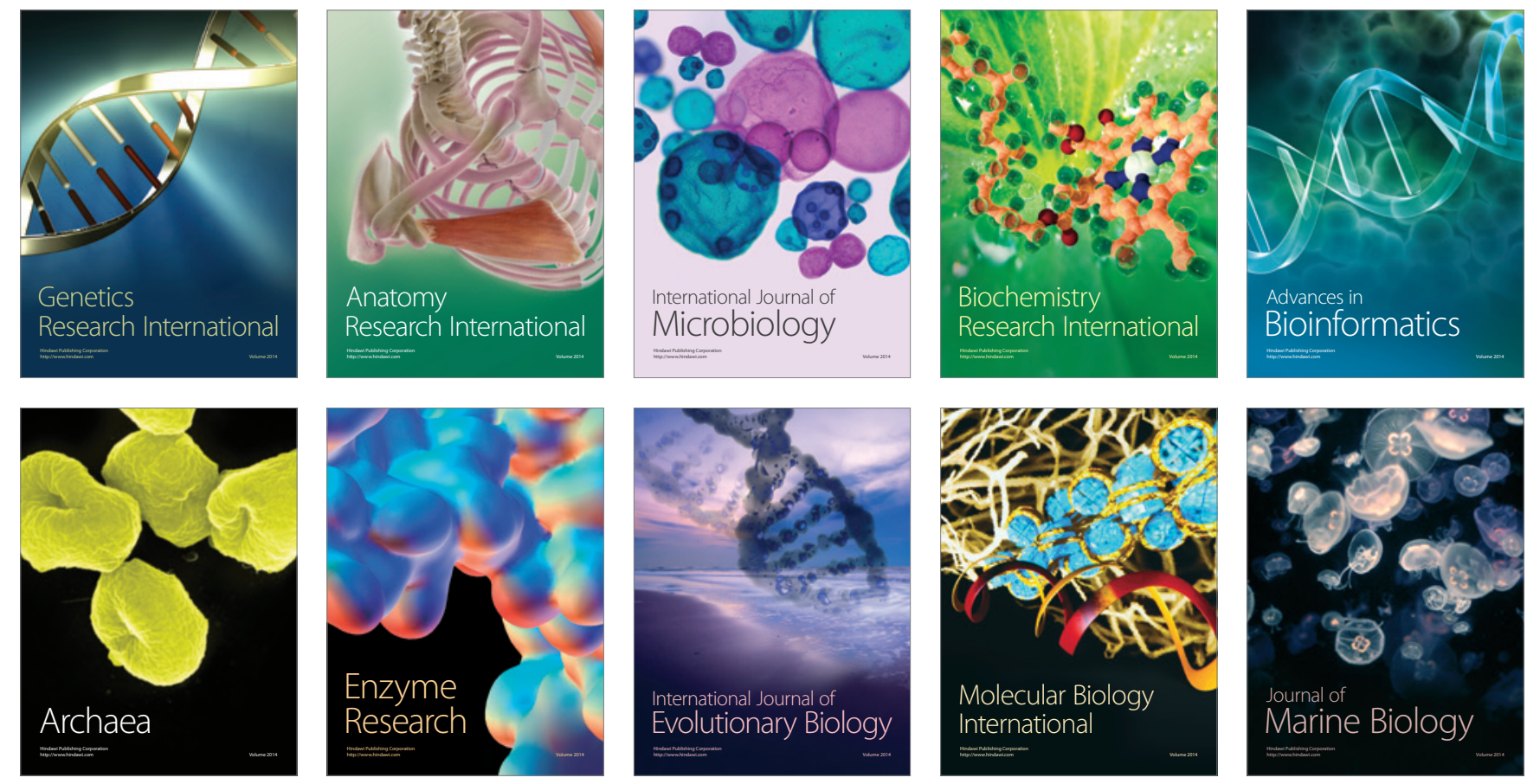